\title{
Effect of dietary supplementation of formic acid, butyric acid or their combination on carcass and meat characteristics of broiler chickens
}

\author{
S. Sugiharto ${ }^{1, *}$, T. Yudiarti ${ }^{1}$, I. Isroli ${ }^{1}$, E. Widiastuti ${ }^{1}$, H. I. Wahyuni ${ }^{1}$, T. A. Sartono ${ }^{1}$, \\ N. Nurwantoro ${ }^{2}$ and A. N. Al-Baarri ${ }^{2,3}$ \\ ${ }^{1}$ Department of Animal Science, Faculty of Animal and Agricultural Sciences, \\ Diponegoro University, Tembalang Campus, Semarang 50275, Central Java - Indonesia \\ ${ }^{2}$ Department of Food Technology, Faculty of Animal and Agricultural Sciences, Diponegoro University, \\ Tembalang Campus, Semarang 50275, Central Java - Indonesia \\ ${ }^{3}$ Integrated Laboratory, Diponegoro University, Semarang 50275, Central Java - Indonesia \\ *Corresponding E-mail:sgh_undip@yahoo.co.id
}

Received April 10, 2019; Accepted July 10, 2019

\begin{abstract}
ABSTRAK
Penelitian ini bertujuan mengkaji pengaruh suplementasi asam format, asam butirat atau kombinasi keduanya terhadap karakteristik daging ayam broiler. Sejumlah 288 ekor ayam broiler (Lohmann MB202) didistribusikan ke empat kelompok perlakuan, termasuk CONT (pakan basal tanpa imbuhan pakan sebagai kontrol), FORM (pakan basal ditambah dengan asam format $0,1 \%$ ), BUTR (pakan basal dengan $0,03 \%$ asam butirat) dan FORM+BUTR (pakan basal dengan $0,1 \%$ format dan $0,03 \%$ asam butirat). Pada hari ke-35 ayam dipotong dan daging bagian dada diambil untuk dianalisis lebih lanjut. Karkas dan potongan komersial ayam tidak berbeda $(\mathrm{P}>0,05)$ antara kelompok CONT, FORM dan BUTR. Kombinasi asam format dan butirat meningkatkan $(\mathrm{P}<0,05)$ berat relatif punggung ayam broiler. Nilai $\mathrm{pH}$ lebih tinggi $(\mathrm{P}<0,05)$ pada daging ayam yang diberi asam organik daripada pada ayam kontrol. Asam organik menurunkan $(\mathrm{P}<0,05)$ drip loss daging. Asam butirat meningkatkan $(\mathrm{P}<0,05)$ kadar air dan menurunkan $(\mathrm{P}<0,05)$ kandungan protein daging. Asam format meningkatkan $(\mathrm{P}<0,05)$, sedangkan asam butirat dan kombinasi asam format dan butirat menurunkan $(\mathrm{P}<0,05)$ nilai lightness daging ayam. Nilai yellowness daging meningkat $(\mathrm{P}<0,05)$ dengan pemberian asam organik. Bands $25 \mathrm{kDa}$ (fosfogliserat mutase) dapat diamati dengan jelas pada sebagian besar sampel daging ayam yang diberi asam organik, tetapi tidak terlalu jelas pada daging ayam kontrol. Sebagai kesimpulan, asam organik dapat memperbaiki kualitas daging ayam broiler. Perlakuan dengan asam organik dapat mencegah kondisi pale, soft and exudative (PSE) pada daging broiler.
\end{abstract}

Kata kunci: asam organic, ayam broiler, kualitas daging, potongan komersial

\section{ABSTRACT}

The objective of the present study was to evaluate the impact of dietary supplementation of formic acid, butyric acid or their combination on carcass and meat characteristics of broiler chicks. A number of 288 day-old-chicks (Lohmann MB-202 meat broilers) were distributed to four groups, including CONT (basal diet with no additive as a control), FORM (basal diet containing $0.1 \%$ formic acid), BUTR (basal diet with $0.03 \%$ butyric acid) and FORM+BUTR (basal diet with $0.1 \%$ formic and $0.03 \%$ butyric acid). At day 35 the birds were slaughtered and eviscerated, and from which the breast meat was obtained. 
Carcass and cut yields of broilers were not different ( $\mathrm{P}>0.05)$ among CONT, FORM and BUTR birds. The combination of formic and butyric acids increased $(\mathrm{P}<0.05)$ the relative weight of back of broilers. Meat $\mathrm{pH}$ value was higher $(\mathrm{P}<0.05)$ in organic acids treated than in non-treated birds. Organic acids lowered $(\mathrm{P}<0.05)$ drip loss of broiler meat. Butyric acid increased $(\mathrm{P}<0.05)$ moisture and decreased $(\mathrm{P}<0.05)$ the content of meat protein. Formic acid increased $(\mathrm{P}<0.05)$, whereas butyric acid and combination of formic and butyric acids decreased $(\mathrm{P}<0.05)$ lightness values of breast meat. Yellowness values of meat increased $(\mathrm{P}<0.05)$ with organic acid administration. Intense bands of $25 \mathrm{kDa}$ (phosphoglycerate mutase) was observed in most of meat samples from the treated birds, but not in meat from the control birds. In conclusion, dietary supplementation of organic acids was capable of improving the meat quality of broiler meats. The treatments may prevent the pale, soft and exudative (PSE)-like condition in broiler meats.

\section{Keywords:broilers, commercial cut, meat quality, organic acid}

\section{INTRODUCTION}

Besides promoting the health and growth rate, the use of antibiotic growth promoter (AGP) in rations has been subjected to improve the yield and characteristics of broiler products. Dietary inclusion of AGP resulted in heavier carcass and commercial portions of broilers (Onifade, 1997). Khaksefidi and Rahimi (2005) further reported that AGP increased and decreased protein and fat contents of broiler meat, respectively. Likewise, our former study showed decreased abdominal fat as well as increased protein content in broiler breast meat with AGP administration (Sugiharto et al., 2017). Nonetheless, the residual effect of antibiotics in broiler meat on consumers (antibiotics may induce the development of antibiotic resistance) has imposed on the ban of AGP in broiler production (Sugiharto, 2016). The latter condition has eventually encouraged the attempt to find alternatives to AGP, as the withdrawal of AGP from diets implies in the health and growth problems in broiler production. Probiotics, prebiotics, synbiotics and phytobiotics are among the most common examples of AGP alternatives. In addition to health and growth promoting effects, these additives have been reported to positively affect the qualities and yield of broiler meat (Takahashi et al., 2005; Grashorn, 2010; Abdulla et al., 2017; Cheng et al., 2017; Park et al., 2017; Tavaniello et al., 2018).

Organic acids (e.g., formic and butyric acid) are another examples of AGP alternative that has widely been used in poultry diets. As feed additive, the products were able to maintain the wellbeing and promote the growth rate of broilers (Kaczmarek et al., 2016; Khan dan Iqbal, 2016; Pathak et al., 2017). In the market, organic acids are available in the form of either single or in combination. According to Sugiharto (2016), combinations of organic acids are more effective in promoting the health and growth performance of broilers as compared to single acid. With regard to the carcass and meat characteristics, the effect of formic acid, butyric acid and their combination has, however, never been revealed. Therefore, the present study aimed to evaluate the effect of dietary supplementation of formic acid, butyric acid or their combination on carcass and meat characteristics of broilers.

\section{MATERIALS AND METHODS}

A number of 288 chicks (day-old Lohmann MB-202 broilers; body weight $[\mathrm{BW}]=45.2 \pm 0.37$ g) were employed in the current study. The birds were allocated to four treatment groups, i.e., CONT (basal diet without additive as a control), FORM (basal diet with $0.1 \%$ formic acid), BUTR (basal diet with $0.03 \%$ butyric acid) and FORM+BUTR (basal diet containing $0.1 \%$ formic and $0.03 \%$ butyric acid). Formic acid (Baymix Latibon ${ }^{\circledR P l u s}$ ME, Dr. Eckel GmbH, Niederzissen, Germany) and butyric acid (Butipearl, Kemin Cavriago, Italy) were incorporated ("on top") at the expense of the feeds. The doses of additives were applied according to the manufacturer's recommendations. The birds were reared in an open-sided broiler house using rice husk as a bedding material throughout the study period. The diets and water were given ad libitum to all birds for the entire trial (days 0-35). The diets were formulated as starter (Table 1) and finisher diets (Table 2), and complied the Indonesian National Standards for Broiler Feed (SNI, 2006). The diets were offered in mash form and contained no antibiotics, coccidiostat, enzymes, anti-mold and anti-fungal agents and other feed additives/supplements.

At day 0 , all birds were vaccinated using commercial avian influenza vaccine (AIV) and Newcastle disease vaccine (NDV) using aerosol 
Table 1. Ingredients and Chemical Compositions of Starter diet (day 0-21)

\begin{tabular}{|c|c|}
\hline $\begin{array}{c}\text { Items }(\% \text {, unless otherwise } \\
\text { noted })\end{array}$ & Composition \\
\hline Yellow corn & 45.5 \\
\hline SBM & 17.0 \\
\hline Wheat flour & 10.0 \\
\hline Bread flour & 5.00 \\
\hline Rice bran & 4.45 \\
\hline $\mathrm{CPO}$ & 3.50 \\
\hline CGM & 3.60 \\
\hline DDGS & 3.00 \\
\hline MBM & 2.80 \\
\hline Chicken feather meal & 2.00 \\
\hline Bone meal & 1.50 \\
\hline Lysine & 0.55 \\
\hline Methionine & 0.37 \\
\hline L-threonine & 0.08 \\
\hline Salt & 0.15 \\
\hline Premix $^{1}$ & 0.50 \\
\hline \multicolumn{2}{|l|}{ Nutrient contents: } \\
\hline $\operatorname{ME}(\mathrm{kcal} / \mathrm{kg})^{2}$ & 3,000 \\
\hline $\mathrm{CP}$ & 22.0 \\
\hline Crude fat & 5.00 \\
\hline Crude fibre & 5.00 \\
\hline Ash & 7.00 \\
\hline \multicolumn{2}{|c|}{$\begin{array}{l}{ }^{1} \text { Premix contained (per kg of diet) of Ca } 2.250 \mathrm{~g}, \mathrm{P} \\
0.625 \mathrm{~g}, \mathrm{Fe} 3.570 \mathrm{mg}, \mathrm{Cu} 0.640 \mathrm{mg} \text {, Mn } 5.285 \mathrm{mg} \text {, } \\
\mathrm{Zn} 0.003 \mathrm{mg} \text {, Co } 0.001 \mathrm{mg} \text {, Se } 0.013 \mathrm{mg} \text {, I } 0.016 \\
\mathrm{mg} \text {, vitamin A } 375 \mathrm{IU} \text {, vitamin D } 150 \mathrm{IU} \text {, vitamin E } \\
0.080 \mathrm{mg} \\
{ }^{2} \text { Metabolizable energy was calculated according to } \\
\text { formula (Bolton, } 1967 \text { ) as follow: } 40.81\{0.87 \\
\text { [crude protein }+2.25 \mathrm{crude} \text { fat }+ \text { nitrogen-free } \\
\text { extract] + } 2.5\} \\
\text { SBM: soybean meal, CPO: crude palm oil, CGM: } \\
\text { corn gluten meal, DDGS: distiller dried grains with } \\
\text { solubles, MBM: meat bone meal, ME: } \\
\text { metabolizable energy, CP: crude protein }\end{array}$} \\
\hline
\end{tabular}

spraying. At day 35 , the birds were weighed and one bird from each pen (6 birds per treatment group) was taken and slaughtered. Upon
Table 2. Ingredients and chemical composition of finisher diet (day 22-35)

\begin{tabular}{lc}
\hline $\begin{array}{l}\text { Items (\%, unless otherwise } \\
\text { noted) }\end{array}$ & Composition \\
\hline Yellow corn & 64.0 \\
SBM & 20.0 \\
PMM & 10.9 \\
Rice & 2.30 \\
Coconut oil & 1.50 \\
Methionine & 0.30 \\
Lysine & 0.20 \\
Dicalcium phosphate & 0.30 \\
Premix ${ }^{1}$ & 0.50 \\
Nutrient contents: & \\
ME (kcal/kg) ${ }^{2}$ & 3,064 \\
CP & 20.0 \\
Crude fat & 5.17 \\
Crude fibre & 5.13 \\
Ash & 7.00 \\
\hline
\end{tabular}

${ }^{1}$ Premix contained (per kg of diet) of Ca $2.250 \mathrm{~g}, \mathrm{P}$ $0.625 \mathrm{~g}$, Fe $3.570 \mathrm{mg}$, Cu $0.640 \mathrm{mg}$, Mn $5.285 \mathrm{mg}$, Zn $0.003 \mathrm{mg}$, Co $0.001 \mathrm{mg}$, Se $0.013 \mathrm{mg}$, I 0.016 $\mathrm{mg}$, vitamin A $375 \mathrm{IU}$, vitamin D $150 \mathrm{IU}$, vitamin E $0.080 \mathrm{mg}$

${ }^{2}$ Metabolizable energy was calculated according to formula (Bolton, 1967) as follow: $40.81\{0.87$ [crude protein +2.25 crude fat + nitrogen-free extract] +2.5$\}$

SBM: soybean meal, PMM: poultry meat meal, ME: metabolizable energy, CP: crude protein

evisceration, the birds were divided into commercial portions, and from which the commercial cuts of broilers were determined. Breast meat were then obtained for the assessment of meat characteristics.

The measurements of $\mathrm{pH}$ and drip loss were conducted based on Wang et al. (2015) with few modifications. The sample of breast meat was weighed and the $\mathrm{pH}$ was determined at about 45 min following slaughter. The meat was subsequently put in a Whirl-pak bag and stored in a $4^{\circ} \mathrm{C}$-refrigerator until $24 \mathrm{~h}$. The sample was reweighed and the $\mathrm{pH}$ was then measured. The drip loss of breast meat was estimated on the basis of weight loss during storing at the refrigerator 
and presented as percentage. To determine the chemical composition of breast meat, proximate analysis was conducted based on the standard methods (AOAC, 1995). The water holding capacity (WHC) of meat was measured according to press methods with filter paper according to Grau and Hamm (1953). The colour of broiler breast meat was assessed using a digital colour meter in Mac OS X (set to CIE Lab). The colour was presented as L* (lightness), a* (redness) and $\mathrm{b}^{*}$ (yellowness) values. To assess the myofibrillar protein in broiler breast meat, Sodium Dodecyl Sulphate Polyacrylamide Gel Electrophoresis (SDS-PAGE) was employed according to AlBaarri et al. (2018) with few modification particularly in the gel concentration. To yield the obvious separation of bands, the gradient of polyacrylamide gel concentration from 4 to $15 \%$ (Bio-Rad Laboratories) was used.

The data of carcass, cut yields and physical and chemical characteristics of broiler meat were subjected to analysis of variance using the General Linear Models Procedure in SAS (SAS Inst. Inc., Cary, NC, USA). Duncan's multiplerange test was further performed when the differences $(\mathrm{P}<0.05)$ among groups were found. Data on the myofibrillar protein profiles were not statistically analysed.

\section{RESULTS AND DISCUSSION}

The effects of organic acid supplementation on commercial proportions of chicks are shown in Table 3. The carcass and cut yields of broilers were not different $(\mathrm{P}>0.05)$ among CONT, FORM and BUTR birds. In accordance with our data, García et al. (2007) documented no significant effect of feeding 5,000 ppm and 10,000 ppm of formic acid on the weights (relative to live body weight) of carcass, breast as well as thigh of broilers. Likewise, Leeson et al. (2005) revealed no substantial effects of butyric acid (at the levels of 0.2 and $0.4 \%$ ) on the carcass and breast meat relative weights in broiler chickens. Different from the single administration, the combination of formic and butyric acids increased $(\mathrm{P}<0.05)$ the proportion of back of broiler chicken in this present study. There was no definite explanation for the latter condition, but it was most likely that the increased live weight of broilers with feeding the combination of formic and butyric acids (1216, 1265, 1256 and $1313 \mathrm{~g}$ for CONT, FORM, BUTR and FORM+BUTR, respectively) resulted in increased cut yield especially the back of broilers. Previously, Mohammed (2016) revealed that the increased cut yield in broilers provided with acetic acid may be attributed to the increased live weight of the respective chicks.

Table 3. Carcass and Cut Yields of Broilers

\begin{tabular}{lcccccc}
\hline \multicolumn{1}{c}{ Items } & CONT & FORM & BUTR & FORM+BUTR & SE & P value \\
\hline \multirow{7}{*}{ Eviscerated carcass } & 66.3 & 65.9 & 66.7 & 66.5 & 0.78 & 0.91 \\
Giblets & 4.63 & 4.44 & 4.69 & 4.96 & 0.27 & 0.61 \\
& \multicolumn{7}{c}{$\%$ Live Weight } \\
Breast & 36.8 & 35.0 & 35.5 & 33.7 & 1.06 & 0.25 \\
Thigh & 16.3 & 15.7 & 16.7 & 15.8 & 0.54 & 0.53 \\
Drumstick & 14.5 & 14.9 & 14.8 & 14.0 & 0.33 & 0.24 \\
Wing & 11.2 & 11.6 & 10.9 & 11.4 & 0.27 & 0.31 \\
Back & $21.0^{\mathrm{b}}$ & $21.9^{\mathrm{ab}}$ & $21.6^{\mathrm{b}}$ & $23.0^{\mathrm{a}}$ & 0.43 & 0.03 \\
Abdominal fat & 1.29 & 1.31 & 1.93 & 2.14 & 0.29 & 0.11 \\
\hline
\end{tabular}

${ }^{a, b}$ Means in the same row with different letters show significant differences $(\mathrm{P}<0.05)$

CONT: basal diet without additive, FORM: basal diet supplemented with $0.1 \%$ formic acid, BUTR: basal diet supplemented with $0.03 \%$ butyric acid, FORM+BUTR: basal diet supplemented with $0.1 \%$ formic acid and $0.03 \%$ butyric acid 
Data on physical and chemical characteristics of broiler meats are shown in Table 4. At both times of measurement (45 min and 24 $\mathrm{h}$ following slaughter), the meat $\mathrm{pH}$ was higher $(\mathrm{P}<0.05)$ in organic acids fed than in control birds. In line with our study, Menconi et al. (2014) showed that treatment with organic acids (lactic, acetic, tannic, propionic and caprylic acids) through drinking water increased the $\mathrm{pH}$ value of broiler meat. There was no exact explanation for the capacity of organic acids in increasing the $\mathrm{pH}$ of broiler meat, but El-Senousey et al. (2013) documented that feeding organic acid (alpha lipoic acid) decreased muscle glycolysis postmortem and thus inhibited the $\mathrm{pH}$ decline in meat following slaughter. In term of meat quality, Kato et al. (2013) classified broiler meat as a pale, soft and exudative (PSE) meat when the $\mathrm{pH}$ is $\leq 5.8$, while the normal meat has $\mathrm{pH}>5.8$. Owing to this, it could be inferred that meat from the chicks treated with formic, butyric and their combination belonged to normal, whereas control meat tended to be PSE meat. It was apparent in this present study that feeding organic acids resulted in lower $(\mathrm{P}<0.05)$ drip loss in broiler meat. Corresponding to our result, El-Senousey et al. (2013) showed a decreased drip loss in broiler meat with feeding alpha lipoic acid. Likewise, Menconi et al. (2014) noticed a decreased drip loss in broiler meat with drinking organic acids (blends of acetic, lacticm tannic, caprylic and propionic acids). Earlier report by Menconi et al. (2014) documented that drip loss was inversely proportional to the WHC value and moisture content in meats. Hence, organic acid treatment, especially by butyric acid, seemed to be responsible for the increased moisture content and thereby decreased drip loss values of broiler meat in the present study. Inconsistent findings were, however, seen in our study, in that feeding the blends of formic and butyric acids decreased WHC of meat, as compared to that of control. In accordance with our data, Attia et al. (2018) reported a reduced WHC in broiler meat with feeding citric and fumaric acids. The inconsistence between our finding and the former data was most likely due to the variations in the organic acid types, feed composition and condition of the studies.

In this study, meat from butyric acid supplemented chicks had less $(\mathrm{P}<0.05)$ content of crude protein than that from other chicks. This result was in contrast to that of formerly noticed by Attia et al. (2018), in which dietary supplementation of $30 \mathrm{~g} / \mathrm{kg}$ fumaric acids elevated

Table 4. Physical and Chemical Characteristics of Broiler Meats

\begin{tabular}{lcccccc}
\hline \multicolumn{1}{c}{ Items } & CONT & FORM & BUTR & FORM+BUTR & SE & P value \\
\hline $\mathrm{PH}_{45 \text { min }}$ & $5.82^{\mathrm{b}}$ & $6.10^{\mathrm{a}}$ & $6.18^{\mathrm{a}}$ & $6.21^{\mathrm{a}}$ & 0.04 & $<0.01$ \\
$\mathrm{PH}_{24 \mathrm{~h}}$ & $5.57^{\mathrm{b}}$ & $5.92^{\mathrm{a}}$ & $5.95^{\mathrm{a}}$ & $5.95^{\mathrm{a}}$ & 0.04 & $<0.01$ \\
Drip loss (\%) & $3.79^{\mathrm{a}}$ & $2.33^{\mathrm{b}}$ & $2.08^{\mathrm{b}}$ & $1.82^{\mathrm{b}}$ & 0.34 & $<0.01$ \\
WHC (\%) & $42.6^{\mathrm{a}}$ & $43.2^{\mathrm{a}}$ & $41.8^{\mathrm{ab}}$ & $41.1^{\mathrm{b}}$ & 0.47 & 0.03 \\
Moisture (\%) & $74.4^{\mathrm{b}}$ & $74.5^{\mathrm{b}}$ & $75.1^{\mathrm{a}}$ & $74.5^{\mathrm{b}}$ & 0.08 & $<0.01$ \\
Crude protein (\%) & $23.5^{\mathrm{a}}$ & $23.3^{\mathrm{a}}$ & $22.5^{\mathrm{b}}$ & $23.2^{\mathrm{a}}$ & 0.17 & $<0.01$ \\
Crude fat (\%) & 0.93 & 0.92 & 0.94 & 0.93 & 0.05 & 0.99 \\
Ash (\%) & 0.85 & 0.78 & 0.73 & 0.86 & 0.04 & 0.09 \\
$\mathrm{~L}^{*}$ (lightness) & $48.5^{\mathrm{b}}$ & $54.8^{\mathrm{a}}$ & $34.9^{\mathrm{c}}$ & $32.8^{\mathrm{c}}$ & 1.15 & $<0.01$ \\
$\mathrm{a}^{*}$ (redness) & $5.44^{\mathrm{b}}$ & $1.89^{\mathrm{b}}$ & $18.8^{\mathrm{a}}$ & $17.2^{\mathrm{a}}$ & 1.36 & $<0.01$ \\
$\mathrm{~b}^{*}$ (yellowness) & $26.8^{\mathrm{c}}$ & $30.6^{\mathrm{b}}$ & $32.7^{\mathrm{ab}}$ & $33.8^{\mathrm{a}}$ & 0.82 & $<0.01$ \\
\hline
\end{tabular}

a,b,c Means in the same row with different letters show significant differences $(\mathrm{P}<0.05)$

CONT: basal diet without additive, FORM: basal diet supplemented with $0.1 \%$ formic acid, BUTR: basal diet supplemented with $0.03 \%$ butyric acid, FORM+BUTR: basal diet supplemented with $0.1 \%$ formic acid and $0.03 \%$ butyric acid, WHC: water holding capacity 
the crude protein of broiler muscles. Yet, the latter authors further reported no substantial effect of feeding 15 and $30 \mathrm{~g} / \mathrm{kg}$ citric acids as well as 15 $\mathrm{g} / \mathrm{kg}$ fumaric acids on crude protein contents of broiler meats. Moreover, study in pig showed no effect of organic acids containing lactic acid, fumaric acid, calcium formate and phosphoric acid on the crude protein content of carcass (Thuy, 2018). To date, the reason for such discrepancies in crude protein content of meat due to organic acids treatment remains unclear. In vitro study demonstrated that butyric acid could induce oxidative stress in some types of cells (Cueno et al., 2015). For this reason, butyric acid supplementation may induce protein oxidation resulting in protein fragmentation (and thus decreased crude protein content) in broiler meats (Soladoye et al., 2015). However, the latter inference should be taken with caution as Zhang et al. (2011) reported that dietary supplementation of sodium butyrate was capable of alleviating the oxidative stress in broiler chicks exposed to corticosterone. The differences in the nature of butyric acid, levels and other experimental conditions may explain the divergent data above.

It was reported in this study that feeding formic acid enhanced $(\mathrm{P}<0.05)$, whereas butyric acid and combination of formic and butyric acids decreased $(\mathrm{P}<0.05)$ the lightness values of broiler breast meat. Former study by Menconi et al. (2014) reported a decreased lightness values in broiler meat with administration of organic acids. Similarly, Göksoy et al. (2010) showed that dietary incorporation of organic acids (combination of $200 \mathrm{~g} / \mathrm{kg}$ lactic acid, $250 \mathrm{~g} / \mathrm{kg}$ formic acid, and $80 \mathrm{~g} / \mathrm{kg}$ propionic acid) numerically decreased the lightness values of broiler breast meat. It has been documented that muscle myoglobin damage was attributable to the change in broiler meat colour, in that myoglobin destruction resulted in increased lightness and decreased redness values of broiler meat (Mir et al., 2017). Apart from its benefits on host defence against pathogens, organic acid may act as stressor leading to physiological deterioration and internal organ disruption (including skeletal muscle) in poultry and other monogastric animals (Nourmohammadi and Khosravinia, 2015: Suiryanrayna and Ramana, 2015). In the case of formic acid, the high acidity of this compound seemed to induce the damage of myoglobin in skeletal muscle (Nourmohammadi and Khosravinia, 2015) and thereby increased the lightness values of FORM compared to other meats. Considering the lower lightness values of BUTR and FORM+BUTR compared to CONT and FORM meats, it was therefore most likely that butyric acid and combination of formic and butyric acids were capable of preventing myoglobin destruction in the muscle and thereby reducing and increasing the lightness and redness values of meat, respectively. In relation to stressors, the increased level of corticosterone has been suggested to induce the muscle myoglobin destruction in broilers (Kannan et al., 1998). Indeed, earlier study showed the capacity of sodium butyrate in inhibiting the increased level of corticosterone in broiler chicks due to bacterial infection. Such organic acid was also capable of ameliorating stress-induced catabolism and oxidative tissues destruction in infected broilers (Zhang et al., 2011). In this respect, butyric acid seemed to be able to control the stress condition (and hence the corticosterone level) in broiler and thereby preventing myoglobin destruction. This inference should, however, be noted with caution as the yellowness values of broiler meat increased $(\mathrm{P}<0.05)$ with feeding organic acids in the present study. Indeed, King and Chen Pas (1998) attributed the increased yellowness values in broiler meats with the increased level of adrenocorticotropic hormone.

It was noted in this present study that intense bands of $25 \mathrm{kDa}$ (phosphoglycerate mutase) was observed in most of meat samples from the organic acids-treated birds. Conversely, the bands of $25 \mathrm{kDa}$ were not intense in meat samples from the control birds (Figure 1). Mudalal et al. (2014) suggested that phosphoglycerate mutase has often been attributed to PSE-like condition in broiler meats. Hence, the less intense of bands of $25 \mathrm{kDa}$ in meats of the treated birds may indicate that feeding organic acids resulted in better meat quality. This inference was inspired by the fact that meats from organic acids fed-birds had higher $\mathrm{pH}$ values and lower drip loss. With regard to the lightness of meats, the $L^{*}$ values of meats from the treated birds particularly from BUTR and FORM+BUTR birds were seen to be lower than that from CONT birds. Indeed, Karunanayaka et al. (2016) reported that PSE-like condition in broiler meats is associated with the lower $\mathrm{pH}$ values, higher drip loss as well as pale colour of meats. To date, the mechanism by which formic and butyric acids improve the meat quality of broiler meats was largely unknown, but such organic acids may protect the myofibrils from damage. In accordance to our data, previous study 

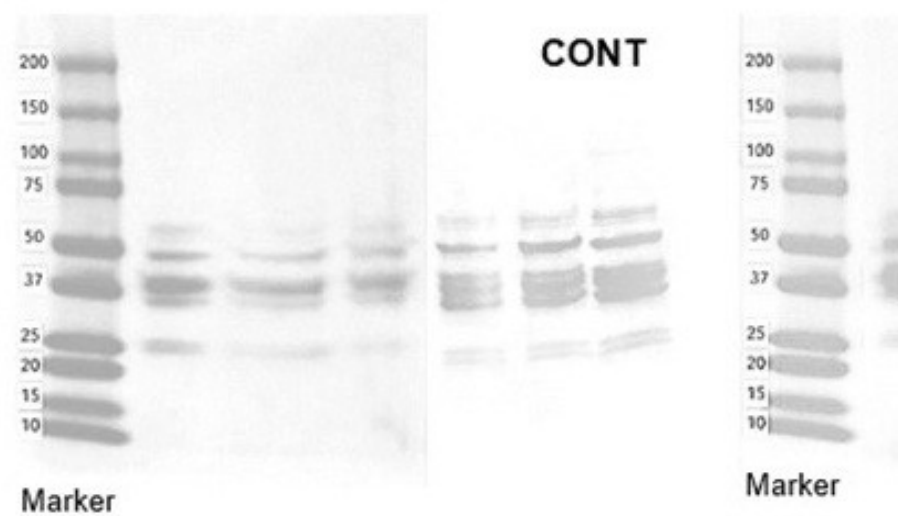

FORM
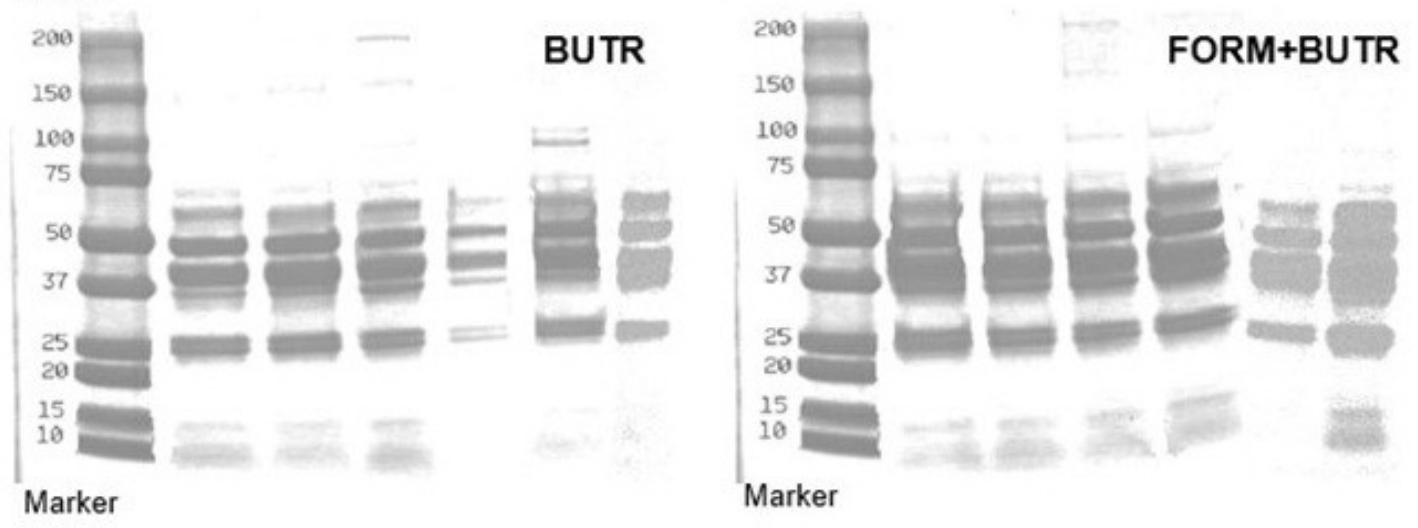

Figure 1. Myofibrillar protein profiles of broiler breast meats on 1D-SDS-PAGE. CONT: basal diet without additive, FORM: basal diet supplemented with $0.1 \%$ formic acid, BUTR: basal diet supplemented with $0.03 \%$ butyric acid, FORM+BUTR: basal diet supplemented with $0.1 \%$ formic acid and $0.03 \%$ butyric acid

by Abudabos et al. (2014) demonstrated that dietary administration of organic acids reduced the extent of destruction of myofibrils in broiler meats.

In most of parameters measured, the effect of organic acids combination was not significantly different when compared with that of individual use of formic or butyric acid. These present findings therefore disagreed to Sugiharto (2016) revealing the more effective of organic acids combination in improving the growth and health condition of broilers compared to individual acid. Unlike the growth and health status, the meat characteristics of broilers are determined not only by the physiological process (internal organs functions during the life), but also the post-harvest processing. The effect of organic acids on broiler meat characteristics seems therefore to be more complex.

\section{CONCLUSION}

Though organic acids did not affect the carcass and cut yields, the combination of formic and butyric acids increased the relative weight of back of broilers. Dietary organic acids supplementation increased the $\mathrm{pH}$ values and lowered drip loss of broiler meat. Butyric acid increased moisture and decreased protein contents of meats. Formic acid increased, whereas butyric acid and combination of formic and butyric acids decreased lightness values of breast meats. Yellowness values of meat increased with organic acid supplementation. The bands of $25 \mathrm{kDa}$ (phosphoglycerate mutase) was more intense in meat samples from the organic acids treated birds compared to that from the control birds. Overall, dietary supplementation of organic acids was potential to improve the meat quality of broiler meats. The organic acids treatments may therefore be beneficial to prevent the PSE-like condition in broiler meats.

\section{REFERENCES}

Abdulla, N. R, A. N. M. Zamri, A. B. Sabow, K. 
Y. Kareem, S. Nurhazirah, F. H. Ling, A. Q. Sazili and T. C. Loh. 2017. Physicochemical properties of breast muscle in broiler chickens fed probiotics, antibiotics or antibiotic-probiotic mix. J. Appl. Anim. Res. 45(1):64-70.

Abudabos, A. M., G. M. Suliman, A. H. Alyemni and A. N. Al-Owaimer. 2014. Effect of different organic acids on breast quality characteristics of broilers challenged with Salmonella enterica. J. Food Agric. Env. 12:193-197.

Attia, F. A. M., H. S. Abd El-Haliem, I. H. Hermes and M. M. A. Mahmoud. 2018. Effect of organic acids supplementation on nutrients digestibility, gut microbiota and immune response of broiler chicks. Egyp. Poult. Sci. J. 38(I):223-239.

Cheng, Y., Y. Chen, X. Li, W. Yang, C. Wen, Y. Kang, A. Wang and Y. Zhou. 2017. Effects of synbiotic supplementation on growth performance, carcass characteristics, meat quality and muscular antioxidant capacity and mineral contents in broilers. J. Sci. Food Agric. 97(11):3699-3705.

Cueno, M. E., N. Kamio, K. Seki, T. KuritaOchiai and K. Ochiai. 2015. High butyric acid amounts induce oxidative stress, alter calcium homeostasis, and cause neurite retraction in nerve growth factor-treated PC12 cells. Cell Stress Chaperon. 20(4):709-713.

El-Senousey, H. K., A. M. Fouad, J. H. Yao, Z. G. Zhang and Q. W. Shen. 2013. Dietary alpha lipoic acid improves body composition, meat quality and decreases collagen content in muscle of broiler chickens. Asian-Australas. J. Anim. Sci. 26(3):394400.

García, V., P. Catala-Gregori, F. Hernandez, M. D. Megias and J. Madrid. 2007. Effect of formic acid and plant extracts on growth, nutrient digestibility, intestine mucosa morphology, and meat yield of broilers. Appl. Poult. Res. 16:555-562.

Göksoy, E. Ö., M. Aksit and S. Kirkan. 2010. The effects of organic acid and origanum onites supplementations on some physical and microbial characteristics of broiler meat obtained from broilers kept under seasonal heat stress. Kafkas Univ. Vet. Fak. Derg. 16:S41-S46.

Grashorn, M. A. 2010. Use of phytobiotics in broiler nutrition - an alternative to infeed antibiotics? J. Anim. Feed Sci. 19:(3)338347.

Mohammed, H. A. 2016. Effect of utilization organic acid supplement on broiler (ROS308) feeding at pre-starter and starter period breeding on basic performance parameters. Int. J. Adv. Res. Biol. Sci. 3(6):76-81.

Kaczmarek, S. A., A. Barri, M. Hejdysz and A. Rutkowski. 2016. Effect of different doses of coated butyric acid on growth performance and energy utilization in broilers. Poult. Sci. 95(4):851-859.

Kannan, G., J. L. Heath, C. J. Wabeck, S. L. Owens and J. A. Mench. 1998. Elevated plasma corticosterone concentrations influence the onset of rigor mortis and meat color in broilers. Poult. Sci. 77(2):322-328.

Karunanayaka, D. S., D. D. Jayasena and C. Jo. 2014. Prevalence of pale, soft, and exudative (PSE) condition in chicken meat used for commercial meat processing and its effect on roasted chicken breast. J. Anim. Sci. Technol. 58: 27.

Kato, T., C. F. Barbosa, E. I. Ida, A. L. Soares, M. Shimokomaki and M. R. Pedrao. 2013. Broiler chicken PSE (pale, soft, exudative) meat and water release during chicken carcass thawing and Brazilian legislation. Braz. Arch. Biol. Technol. 56(6):996-1001.

Khaksefidi, A. and S. H. Rahimi. 2005. Effect of probiotic inclusion in the diet of broiler chickens on performance, feed efficiency and carcass quality. Asian-Australas. J. Anim. Sci. 18(8):1153-1156.

Khan, S. H. and J. Iqbal. 2016. Recent advances in the role of organic acids in poultry nutrition. J. Appl. Anim. Res. 44(1):359369.

King, Y. T., T. C. Chen Pas, R. E. Buresh and J. Brake. 1998. Quality characteristics of broiler meat obtained after adrenocorticotropic hormone-induced stress. Prof. Anim. Sci. 14(1):22-27.

Leeson, S., H. Namkung, M. Antongiovanni and E. H. Lee. 2005. Effect of butyric acid on the performance and carcass yield of broiler chickens. Poult. Sci. 84(9):14181422.

Menconi, A., V. A. Kuttappan, X. HernandezVelasco, T. Urbano, F. Matte, S. Layton, G. Kallapura, J. Latorre, B. E. Morales, O. Prado, J. L. Vicente, J. Barton, R. L. Andreatti Filho, M. Lovato, B. M. Hargis 
and G. Tellez. 2014. Evaluation of a commercially available organic acid product on body weight loss, carcass yield, and meat quality during preslaughter feed withdrawal in broiler chickens: A poultry welfare and economic perspective. Poult. Sci. 93(2):448-455.

Mir, N. A., A. Rafiq, F. Kumar, V. Singh and V. Shukla. 2017. Determinants of broiler chicken meat quality and factors affecting them: a review. J. Food Sci. Technol. 54(10):2997-3009.

Mudalal, S., E. Babini, C. Cavani and M. Petracci. 2014. Quantity and functionality of protein fractions in chicken breast fillets affected by white striping. Poult. Sci. 93(8):21082116.

Nourmohammadi, R. and H. Khosravinia. 2015. Acidic stress caused by dietary administration of citric acid in broiler chickens. Arch. Anim. Breed. 58:309-315.

Onifade, A. 1997. Growth performance, carcass characteristics, organs measurement and haematology of broiler chickens fed a high fibre diet supplemented with antibiotics or dried yeast. Forschungsbeiträge, 41(6).

Park, S. H., S. I. Lee, S. A. Kim, K. Christensen and S. C. Ricke. 2017. Comparison of antibiotic supplementation versus a yeastbased prebiotic on the cecal microbiome of commercial broilers. PLoS ONE. 12:e0182805.

Pathak, M., G. P. Mandal, A. K. Patra, I. Samanta, S. Pradhan and S. Haldar. 2016. Effects of dietary supplementation of cinnamaldehyde and formic acid on growth performance, intestinal microbiota and immune response in broiler chickens. Anim. Prod. Sci. 57((5):821-827.

SNI (Indonesian National Standard). 2006. Standard for broiler feed (SNI 01-39302006). National Standardization Agency of Indonesia, Jakarta, Indonesia

Soladoye, O. P., M. L. Juarez, J. L. Aalhus, P. Shand and M. Est'evez. 2015. Protein oxidation in processed meat: mechanisms and potential implications on human health. Compr. Rev. Food Sci. Food Saf. 14:106-
122.

Sugiharto, S. 2016. Role of nutraceuticals in gut health and growth performance of poultry. J. Saudi Soc. Agric. Sci. 15(2):99-111.

Sugiharto, S., T. Yudiarti, I. Isroli, E. Widiastuti and F. D. Putra. 2017. Effects of feeding cassava pulp fermented with Acremonium charticola on growth performance, nutrient digestibility and meat quality of broiler chicks. S. Afr. J. Anim. Sci. 47(2):130-138.

Suiryanrayna, M. V. A. N. and J. V. Ramana. 2015. A review of the effects of dietary organic acids fed to swine. J. Anim. Sci. Biotechnol. 6: 45.

Takahashi, S. E., A. A. Mendes, E. S. P. B. Saldanha, C. C. Pizzolante, K. Pelícia, R. R. Quinteiro, C. M. Komiyama, R. G. Garcia and I. C. L. Almeida Paz. 2005. Efficiency of prebiotics and probiotics on the performance, yield, meat quality and presence of Salmonella spp in carcasses of free-range broiler chickens. Braz. J. Poult. Sci. 7(3):151-157.

Tavaniello, S., G. Maiorano, K. Stadnicka, R. Mucci, J. Bogucka and M. Bednarczyk. 2018. Prebiotics offered to broiler chicken exert positive effect on meat quality traits irrespective of delivery route. Poult. Sci. 97(8):2979-2987.

Thuy, N. T. 2018. Probiotic and organic acids improve growth performance of pigs fed diets containing Catfish (Pangasius hypophthalmus) protein hydrolysate. Livest. Res. Rural Dev. 30(8).

Wang, D., H. Huang, L. Zhou, W. Li, H. Zhou, G. Hou, J. Liu and L. Hu. 2015. Effects of dietary supplementation with turmeric rhizome extract on growth performance, carcass characteristics, antioxidant capability, and meat quality of Wenchang broiler chickens. Ital. J. Anim. Sci. 14(3):344-349.

Zhang, W. H., Y. Jiang, Q. F. Zhu, D. R. F. Gao, S. F. Dai and J. Chen. 2011. Sodium butyrate maintains growth performance by regulating the immune response in broiler chickens. Br. Poult. Sci. 52(3):292-301. 